\title{
Project Sharing: Public Communication and Education as a Tool for Citizenship Guarantee
}

\author{
Tatyane Ferreira \\ Scientific Researcher IESB University Center, Brasília, Brazil \\ tatymferreira@hotmail.com \\ Alzimar Ramalho \\ PhD Prof. IESB University Center, Brasília, Brazil \\ alzimar.ramalho@gmail.com \\ Márcia Marques \\ PhD Prof. University of Brasília, Brasília, Brazil \\ professoramarcia@gmail.com
}

\begin{abstract}
The article presented the experiences and results of the pedagogical model developed in the project "Partilhar: Comunicação, Informação e Computação para compartilhamento da cidadania", translated as Sharing: Communication, Information and Computing to share citizenship. The research involved four institutions: the University of Brasilia (UnB), the IESB University Center, the João Mangabeira Foundation (FJM) and the Paranoá Culture and Development Center (Cedep), all located in Brasília, capital of Brazil. The cross-cutting theme was Public Transparency - forms of monitoring, use and application of public resources. In the first stage, pedagogical materials were produced and test-workshops were applied focusing on the training of Communication and Information competences in social networks using mobile technologies. The second part consisted on the application of the workshop plan and evaluation of its results and was not yet finalized.

The objective was to inform people to use social media in a network from a citizen perspective, guiding participants to learn how they can autonomously acquire the skills and abilities necessary for the practical appropriation of the mechanisms
\end{abstract}


provided by the Brazilian Transparency Law. This "teaching to learn" also proposed that learners become multipliers of knowledge, always shareable and permanently elaborated/reworked by the collective. It was based on the premise that the main obstacles to inclusion need to be overcome in an articulated way: information poverty, digital exclusion, censorship, the political use of technology, misinformation, manipulation of the media and destruction of public information.

KEY WORDS: Communication, Information and Computing (CIC), educommunication, citizenship, pedagogical model, university extension.

\section{Introduction}

This report presents the actions carried out under the "Partilhar: Comunicação, Informação e Computação para compartilhamento da cidadania" project, translated as Sharing: Communication, Information and Computing to citizenship sharing. The initiative consists of a survey conducted collaboratively between four institutions: the University of Brasília (UnB), IESB University Center, João Mangabeira Foundation (FJM) and Culture and Development Center of Paranoá (Cedep).

Within the University of Brasília (public teaching institution), which heads the initiative, the proposal is registered as an extension project of the Communication Department. At the IESB University Center (private teaching institution), the project is developed within the scientific initiation program. The João Mangabeira Foundation acts as a partner, assisting in the preparation and financing the developed products, and the Culture and Development Center of Paranoá (Cedep) is where the educational model is being tested. All the processes are being developed in the city of Brasilia, capital of Brazil, and in the Administrative Region of Paranoá, which composes the Federal District.

The objective is to develop and test an interdisciplinary model in territorial social networks for the formation of competences in Communication, Information and Computing. This knowledge is contextualized by the transversal theme Public Transparency (access, use and dissemination of information on public policies and ways of monitoring and applying public resources). In this sense, participants are taught, in an autonomous way, to acquire the skills and abilities necessary for the practical appropriation of the Brazilian Transparency Law (Complementary Law No. 131/09, authored by Senator João Capiberibe).

The premise of the "learning to learn networking" (Marques and Ramalho 2017) states that the community becomes a multiplier of knowledge that is permanently open to sharing and restructuring by the collective, in-person or virtually. The research is 
based on the precept that one must articulate in order to overcome the main obstacles to inclusion: the information poverty, digital exclusion, censorship, political use of technology, misinformation, manipulation of the media and destruction of information public (López and Samek 2011).

Teachers and academics from the two educational institutions have teamed up with professionals from the areas of design, audiovisual and journalism to develop the pedagogical materials for the Sharing workshops. From the collective effort, the group developed the Eye on Transparency Collection (De Olho na Transparência in portuguese), which contains a teaching manual and two practical guides - one on public transparency and another on communication and network information. The material was produced for print and digital media, with funding from the João Mangabeira Foundation, and also featured video production and a curatorial site. As the project starts from the precept of open science, all the content produced is public and has open access, which allows all kinds of use, as long as the right to authorship is maintained. The Cedep is an non-governmental organization managed by the community for 30 years, focusing on educational and social mobilization. The institution acts as a test group for the methodology, which will be replicated in Aracaju, in the HispanoBrazilian Seminar on Competence in Information. The project has already been presented in lectures at public and private universities in Amapá, as well as in other Brazilian states. There is also a seminar planned with councilors and deputies from the PSB (Brazilian political party), in exchange for the partnership in the production of teaching material by the João Mangabeira Foundation.

As a territorial test network, Cedep received two workshops in 2016 and 2017, focused on instrumental training in audiovisual language ( 9 hours) and violence against women ( 3 hours), both focusing on public policies, human rights and communication. The second stage occurred in the second half of 2017 to test the 20-hour classroom model proposed in the pedagogical manual, adding the necessary knowledge to the use of the Transparency Law making use of digital media as tools for monitoring and surveillance in search of effectiveness in the application of the public resources in the community where they are inserted.

\section{Theoretical Grounding}

The project used as base the interdisciplinary model developed in the doctoral thesis by Márcia Marques (co-author of this paper), consisting of a communication and information action plan on networked digital and territorial environments (Marques 
2015). The objective is to establish the connection between Communication, Information and Computing (CIC) to enable the development of knowledge and skills for the use of information and for communication in networks in digital environments. The model is a guide for the diagnosis and planning of actions: for the collective construction of negotiated communication relations between the participants of the network; for the creation of digital environments that propitiate learning spaces for the confrontation of information and communication; so that specialists in public communication promote the transparency of information, as provided in the Constitution and the Law on Access to Information in Brazil. A network is made up of people, whether they are digital environment or not, is made of relationships, of communication (Marques 2015).

A learning network (such as a study group, for example), needs to find links that allow it to connect researchers, funders and supporters to mobilize themselves for the construction of a knowledge that is articulated between, beyond and across disciplines (Nicolescu and Morin and Lima de Freitas 1994), enriched by the various approaches, angles, new information, financial resources, contributions etc.

In addition to the role of communication in modern information technology, it must be realized that technologies within the field of computing not only comprise hardware and software, but also the reasoning, symbols, and codes that make the devices "intelligent" and guide the relationships between machines and people, people and people, machines and machines, etc.

The model does not only include the empowerment of citizens in the use of technology, but above all the continuous training aimed at multiplying information in new groups - new configurations of networks - in search of digital citizenship, linked to human rights and citizenship for the information society (Cuevas-Cervero 2013).

To achieve this cyber-citizenship is necessary to mix the teaching, enabling individuals to gain the skills they need to enjoy the right guaranteed in Article 19 of the Universal Declaration of Human Rights, 1948: "Everyone has the right to freedom of opinion and expression; this right includes freedom to hold opinions without interference and to seek, receive and impart information and ideas through any media and regardless of frontiers."

The reasoning of Paulo Freire (1999) is aligned to the proposed literacy of this project, since it is considered that each person is able to gain the intellectual tools necessary to relate to and reinvent the culture in which lives in, critically and liberating, always focusing on the autonomy of those who learn and on constant dialogue, because knowledge is not static, but complex and socially constructed, in a continuous and 
irregular process. This idea of autonomy rescues the self-taught imaginary, seeking to develop processes for which individual to learn to learn - get self-learning skills for the rest of life -, search, select, develop and disseminate the necessary and useful information; can professionally qualify for the use of new technologies; aware of the economic, ideological, political and cultural implications of technology in our society.

\section{Methodology}

Using as reference the communication and information action model in network in digital environments (Marques 2015), the survey counted on the participation of the Paranoá members, especially Cedep, and researchers from the project since the conception until the definition of the communication and information action plan for the network. The training, focused on learning to learn, used mobile devices and the Internet to understand the search, access, use and propagation of information, making use of the perspective of transdisciplinary work between the areas of Information Science, of Computing and Communication.

In order to plan actions for complex networks, focusing on the formation of citizenship, it was used a model that merges methodologies. Simeão and Miranda (2013), consider meta-methodology a tool for the complexity and the confirmation that the scientific method cannot serve a single particular area. This type of methodology is mainly presented in the approach phase of the problem and in the hypothesis and testing phase, as it was done in the Paranoá network.

Although Public Transparency has been used as the theme of the test event, the proposed model can be replicated with any subject. All people interested can adapt the project based on the theme and place of interest, since it respects the culture and reality of each group, as well as their demands. The pedagogical construction process must be done in a collective way taking into consideration which platform is best adapted to the public and the content that will be worked on.

The methodology was applied in an administrative region of the Brazilian federal capital, and because it is a vulnerable place with a low-income population, there was great concern in making the initiatives be developed with the participant's equipment such as personal cell phones. This logistics makes the proposed model easily replicable and may be appropriate, with due credit for authorship, to any institution or civil organization that wishes to develop it, as it follows the precepts of open science.

To prepare the planning of the classes that composes the pedagogical model, two workshops were held-test for evaluation in the community, and one internal, only with 
the scholars of the project. From the results of each of the experiments, a teaching plan with a duration of 20 hours was drawn up, distributed among four weekly meetings, held on Saturdays, with variable hours according to the theme that will be worked out at each meeting.

\subsection{Step 1- Planning, production and testing}

The work plan and the development of the workshops were carried out between August 2016 and April 2017, aiming to test the model in different situations, for the evaluation of the researchers. The month of August was used for the structuring of the project and the definition of the team. In September, the employees started the approximation with the community of Cedep and began to develop the theoretical literature that would accompany the project in the field of public policies and Transparency Law. The first workshop was held in December 2016 by the Professor Alzimar Ramalho, with the theme "Audiovisual Language". This initial contact lasted nine hours, divided into three Saturdays. In February 2017, the photographer Sérgio Amaral (Esso Journalism Award in 2002), with the support from the teacher Alzimar Ramalho, gave the second workshop focused on the project grantees. Working on the theme "Photography and Reading Images", the meeting lasted three hours. At the time, the scholars did a test of adequacy of the content and the time of workshop and audiovisual recording techniques, with two cameras, so that also the full contents of the lectures may be available in the virtual environment.

In the following month, the third workshop composed the Women's Week programming in Cedep with a debate on violence against women in general and community level, lasting 3 hours. The guest was the teacher Kátia Belisário, professor of Organizational Communication at $\mathrm{UnB}$ and researcher of gender issues.

From December 2016 to July 2017, the group prepared the support material for the project: a site with content curation linked to public policies and the Transparency Law, the Eye Collection in Transparency (composed of a pedagogical manual and two guides - one on public transparency and another on network communication and information) to train multipliers and explanatory videos for complex content such as "Budget Cycle" and "Active and Passive Transparency". The material is available at http://www.fjmangabeira.org.br/deolhonatransparencia.

The team had the participation of the $\mathrm{PhD}$ professors Márcia Marques (UNB) and Alzimar Ramalho (IESB University Center), Patrícia Cunegundes (Master's degree in communication), Joyce Del Frari Coutinho and Ana Elizabeth Gomes (journalists 
working in public communication, being the last one the organizer of the book on public transparency). Also participated Tatyane Ferreira (journalist and scientific researcher in journalism at IESB), Carolina Cruz (journalist), Gabriel Oliveira (journalism student at the Paulista University - UNIP), Mário Benisti (recently graduated in journalism at IESB) and Francisco Morais (high school student in youth and adult education modality taught by Cedep). Francisco was invited to join the group due the interest and proactivity shown in the activities proposed in the audiovisual workshop.

The pedagogical manual provides a model of workshop planning, using as base the workshops-tests and their results, designed to be executed in four weekly meetings. The meetings will have a maximum of 20 participants, totaling 20 classroom hours. Within our test phase, with application in September-October, the programming was described as shown bellow.

- Meeting I - Opening: Learning to learn in a network, a proposal for citizen autonomy; presentation of the Sharing project team (UnB-IESB) and workshop objectives and planning. Presentation of participants, group work skills, course expectations and preliminary results of the completed questionnaire at the time of enrollment so that the network is recognized and established. Presentation of the cross-cutting theme: Transparency Law (LC 131/2009) and Law on Access to Information (LAI / 2011) and social monitoring of public policies. Practical application: WhatsApp or Telegram group creation, set in accordance, with minimum rules of coexistence. During the week, students / multipliers will work on the theme Transparency: registering in photos and videos things related to some aspect of transparency and public policies in the places where they live, work or study - in this example, public equipment, such as schools, parks, health clinics, safety equipment, public defender etc; and seeking information about public works or services, in transparency portals or in person. The material should be taken to meeting II with the purpose of provoking reflections on concepts and techniques of audiovisual language, very important when it comes to communication in networks.

- Meeting II - Workshop on photographic and audiovisual language, based on the analysis of the images elaborated by the participants. Evaluation of the information obtained during the week of transparency portals and public agencies and also the step-by-step to expand the research through transparency portals. Activity for the following week: deepen the research of images, audiovisual materials and information in transparency portals and other networks. 
- Meeting III - Network communication: learning to learn collectively and collaboratively in a network, for the culture of information. The importance of personal relationships in physical and digital environments. Practical application in the use of applications for smartphone and communication networks. Supply networks by sharing information with content researched / produced in previous steps. Activity for the week: Finish the curator of an image bank photo and video with information already available under Creative Commons and raise contents to guide people in the use of portals of transparency and Access to Information Act.

- Meeting IV - The place of students' speech, the Cedep multipliers network. Reflection on what has been accomplished and the prospects of multiplying the experience. Presentation of results and actions arising from the research on transparency and public policies in Paranoá. Closing lecture and distribution of certificates. Collective snack closing, with musical activity.

\subsection{Step 2-Planned activities}

Initially, the test-workshops was scheduled to be finished by July 2017, but due to administrative issues with Cedep, workshops could only be scheduled for September / October. The expectation is that in November the results analysis will be ready. Before the end of the process, new explanatory videos will also be produced.

During the workshop, a research form will be applied to support the planning of communication and information actions. The questionnaire was based on the doctoral thesis of professor Márcia Marques, and is an adaptation of the model that appears in the Pedagogical Manual. As mentioned previously, the methodology will also be replicated in Aracaju, at the Hispano-Brazilian Seminar on Information Competence, and presented at lectures at universities in other Brazilian states.

\section{Conclusions}

The complete model, with an emphasis on cross-cutting theme "Public Transparency", considers the CIC tripod, the Communication being present in modules on audiovisual language and social networks; the Information is contemplated in the module of research of data in transparency portals; and Computation, in this context, collaborates in the digital literacy stage for the use of transparency portals, applications for mobile devices and the interpersonal communication itself in the digital environment, 
considering the appropriateness of purposes. The organization of participants in virtual networks, in our understanding, is a fundamental condition for the success of territorial networks (in person).

The project can be adapted to other realities, since all decisions start from the premise of respect for the collective knowledge of each community, as well as their needs. Only from this is it possible to jointly decide on the digital and communicational mechanisms that can serve as channels for effecting social control over the use of public resources in policies such as Health, Education, Mobility or any others that are of direct interest to the participants.

\section{References}

Cuevas-Cerveró, Aurora, and Márcia Marques and Pablo Boaventura. 2014. "A alfabetização que necessitamos: informação e comunicação para a cidadania" [The literacy we need: information and communication for citizenship]. Inf. E Sociedade, v. 24, n. 2, may/ago 2014, 35-48.

Freire, Paulo. 1999. Pedagogia da autonomia: saberes necessários à prática educativa [Pedagogy of autonomyः necessary knowledge for educational practice]. São Paulo: Paz e Terra. First published 1996.

López, P. L., and T. Samek. 2011. "Inclusão Digital: um novo direito humano" [Digital Inclusion: A New Human Right]. In Alfabetização informacional e inclusão digital: modelo de infoinclusão social [Information literacy and digital inclusion: social info inclusion model], edited by Aurora Cuevas-Cerveró and Elmira Simeão, 21-37. Brasília: Thesaurus editora.

Marques, Márcia. 2015. "Modelo de ação comunicativa e de informação para redes sociais em ambientes digitais" [Communicative and information action model for social networks in digital environments]. PhD diss., University of Brasília.

Marques, Márcia, and Ramalho, Alzimar. 2017. Aprender a aprender em rede: manual pedagógico [Learning to learn in a network: pedagogical manual]. Brasília: Editora FJM.

Miranda A. and E. Simeão. 2014. "Da Comunicação Extensiva ao hibridismo da Animaverbivocovisualidade (AV3)" [From the Extensive Communication to the Hybridism of Anima Verbivocovisuality (AV3)]. Inf. E Sociedade, v. 24, n. 3, sep/dec 2014, 49-62.

Nicolescu, B., E. Morin and Lima de Freitas. 1994. "Carta da Transdisciplinaridade" [Letter of Transdisciplinarity]. Accessed Set 12, 2017. http://caosmose.net/candido/unisinos/ textos/textos/carta.pdf.

Unesco. 1948. “Universal Declaration of Humans Rights." Accessed Set 12, 2017. http://www. un.org/en/udhrbook/pdf/udhr_booklet_en_web.pdf. 